\author{
Krzysztof Gasz \\ Dr inż. \\ Politechnika Wrocławska \\ Wydział Budownictwa Lądowego i Wodnego \\ Katedra Dróg i Lotnisk \\ krzysztof.gasz@pwr.edu.pl
}

DOI: 10.35117/A_ENG_20_01_02

\title{
Marking and use of Kiss \& Ride car parks
}

\begin{abstract}
In recent years, Kiss \& Ride car parks have appeared in Polish cities. The idea of the car park is to transfer the passenger to the transfer node, so that the rest of the journey can be done by public transport. Car parks of this type are also located near other places, where it is necessary to lift or pick up another person (for example, near schools, hotels). The article presents marking of Kiss \& Ride car parks in Polish cities. The parking analysis was carried out on four car parks of this type in Wrocław during morning peak and during afternoon peak. The stopping time and purpose of parking were determined.
\end{abstract}

Keywords: Car park; Kiss \& Ride; Wrocław

\section{Introduction}

Since 2013, solutions in the form of Kiss \& Ride parking spaces have been introduced in Polish cities. The name of the car park is not obvious and understandable for all road users, as shown by numerous comments and polls published, for example, on the Internet. Most people can decode the English lettering, but don't know what exactly is going on with kissing and driving at the same time.

Kiss \& Ride car parks are parking spaces intended for short-term parking. Parking lots are most often made in the form of parking bays. Depending on the location, the allowed parking time may vary from one minute to fifteen minutes. Kiss \& Ride car parks are used to park vehicles which carry other people. At this car park, the passenger can easily get out of the car without risking his or her health and life. Such a risk of endangering health occurs when the vehicle is stopped in the lane and the passenger gets off directly onto the road [3]. The passenger can also take his things (e.g. a suitcase) from the car and say goodbye to the driver. After saying goodbye, the vehicle should leave the parking space. Parking lots of this type are located at transfer nodes - railway stations or more important public transport stops in the city. In this way, they are to facilitate and encourage the use of public transport. Thanks to a special marking, they are easily recognizable. Kiss \& Ride car parks are also being introduced in places not necessarily related to changing transport modes. They are used where there is a need to transport other people, e.g. in the area of schools, kindergartens, hotels [2]. Kiss \& Fly zones, located near airports, are a special type of these car parks.

Kiss \& Ride car parks can also be used for the opposite situation when the driver comes and picks up another person. The aim of this article is to investigate the purpose of parking and the duration of parking at Kiss \& Ride car parks.

\section{Marking of Kiss \& Ride car parks in selected Polish cities}

In the Polish technical conditions for road marking [11], there is no separate road sign for marking the Kiss \& Ride car parks. For the sake of fairness, it must be added that there is no such sign in the technical conditions of most countries. Only some countries have separate signs to mark this type of parking, e.g. Czech Republic [14]. An example of valid Kiss \& Ride car park markings in the Czech Republic is shown in Fig. 1. An overview of the Kiss \& Ride 
zone markings used in different countries is presented in detail in the article [4]. On the other hand, the division and characteristics of the Kiss \& Ride zones are presented in the publication [5]. The articles [1, 8, 9, 15] presented models of multimodal travel selection, including the use of Kiss \& Ride car parks.

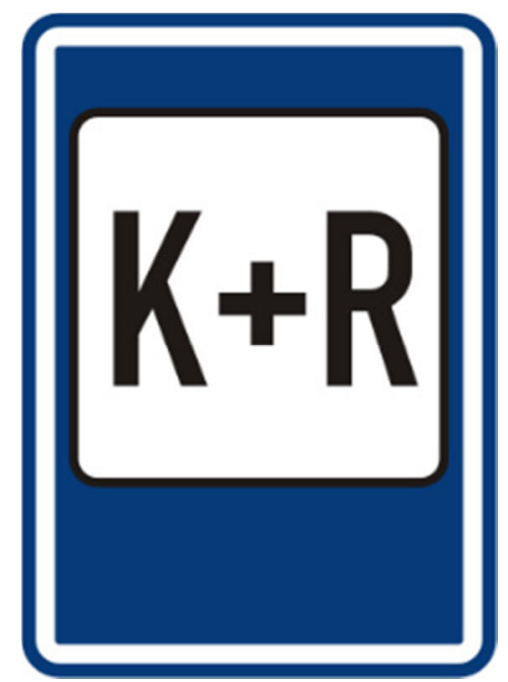

1. Mandatory marking of the Kiss \& Ride car park in Czech Republic [14]

In Polish technical conditions, however, there is information on how to mark places "where, due to traffic conditions, it is necessary to allow a short-term immobilization of the vehicle in order to pick up or drop off a passenger in front of facilities such as: offices, institutions, public buildings, etc. [11 ]. "Such places should be marked with vertical sign B 35 "no parking". Although the guidelines do not provide direct information about Kiss \& Ride car parks, it is clear from them that they should be marked with the B-35 sign. Additionally, information is provided that if it is allowed to stop the vehicle for more than one minute, under the sign or on the plate under the sign, an inscription specifying the time of permitted parking should be placed [11].

Due to the lack of a special sign in the Technical Conditions [11] defining the Kiss \& Ride car park, road managers in Polish cities have different approaches to marking these car parks. There are also situations where different parking lots of this type are marked differently within one city. In most cities, the sign B-35 is used, but the inscriptions on the sign, plates under the sign, road markings are no longer the same.

In Wrocław, Kiss \& Ride car parks started to be used in 2014. The marking consists only of the B-35 sign with the allowed parking time (usually up to 5 minutes, but in some places parking up to 15 minutes is allowed). There is a sign with the Kiss \& Ride car park pictogram under the sign. In Wrocław, Kiss \& Ride car parks are used not only at interchange junctions but also at other public facilities and tourist attractions. An example of marking the Kiss \& Ride car park in Wrocław is shown in Fig. 2. 


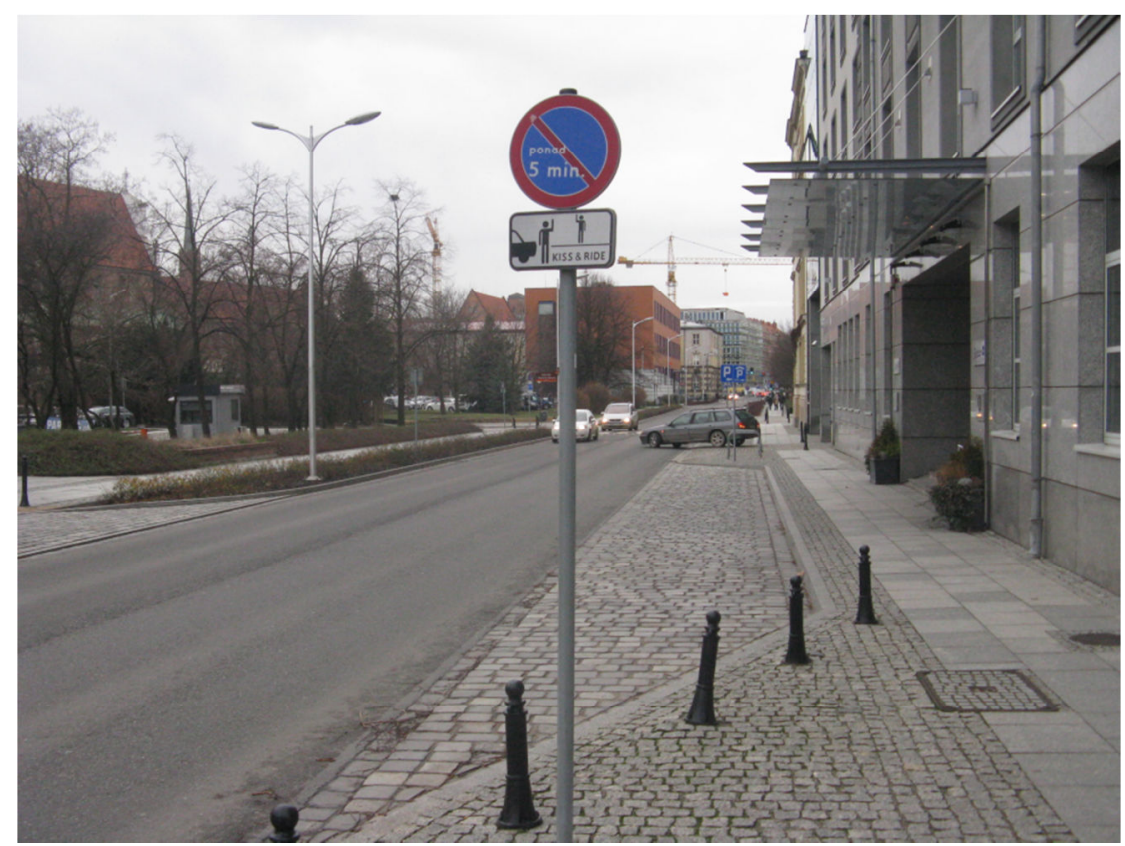

2. Kiss \& Ride car park in Wrocław marking

In Wrocław, in the area of the Main Railway Station, a different method of marking the Kiss \& Ride car park is used. The marking of this car park is presented in Fig. 3. On the pole, among a series of perpendicular parking lots, there is a Kiss \& Ride car park pictogram different from the one commonly used in Wrocław (as in Fig. 2). Due to such marking, it is difficult to determine which places are used as short-stay car parks and whether such parking is actually provided there.

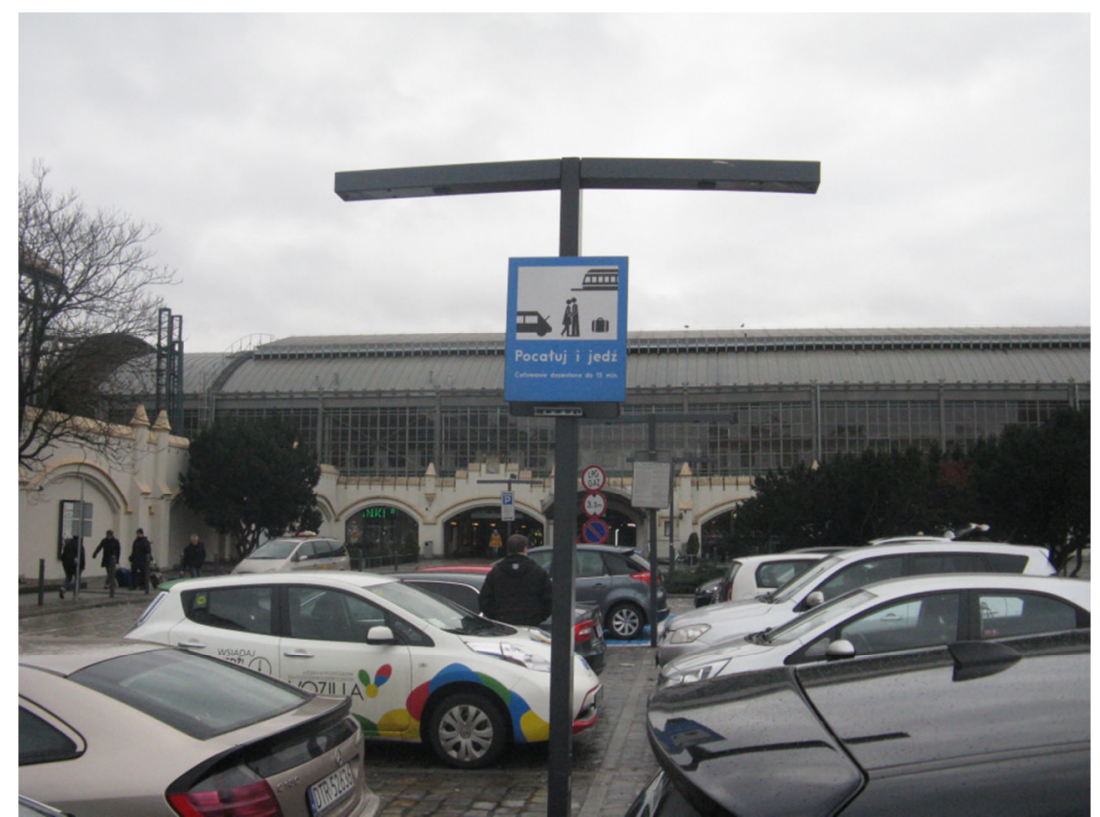

3. Kiss \& Ride car park marking in the area of the Main Railway Station in Wrocław

Kiss \& Ride zones have been operating in Krakow since 2013. The marking of the short-term parking zone consists of a B-35 sign, a plate with information that the sign applies to $\mathrm{K}+\mathrm{R}$ parking spaces, and a pictogram of the Kiss \& Ride zone. This pictogram shows the Polish name of the "Pocałuj i Jedź" zone and the specified "maximum kissing time" (up to 3 
minutes). The sign is supplemented with a colored pictogram on the road. An example of marking the Kiss \& Ride car park in Krakow is shown in Fig. 4.

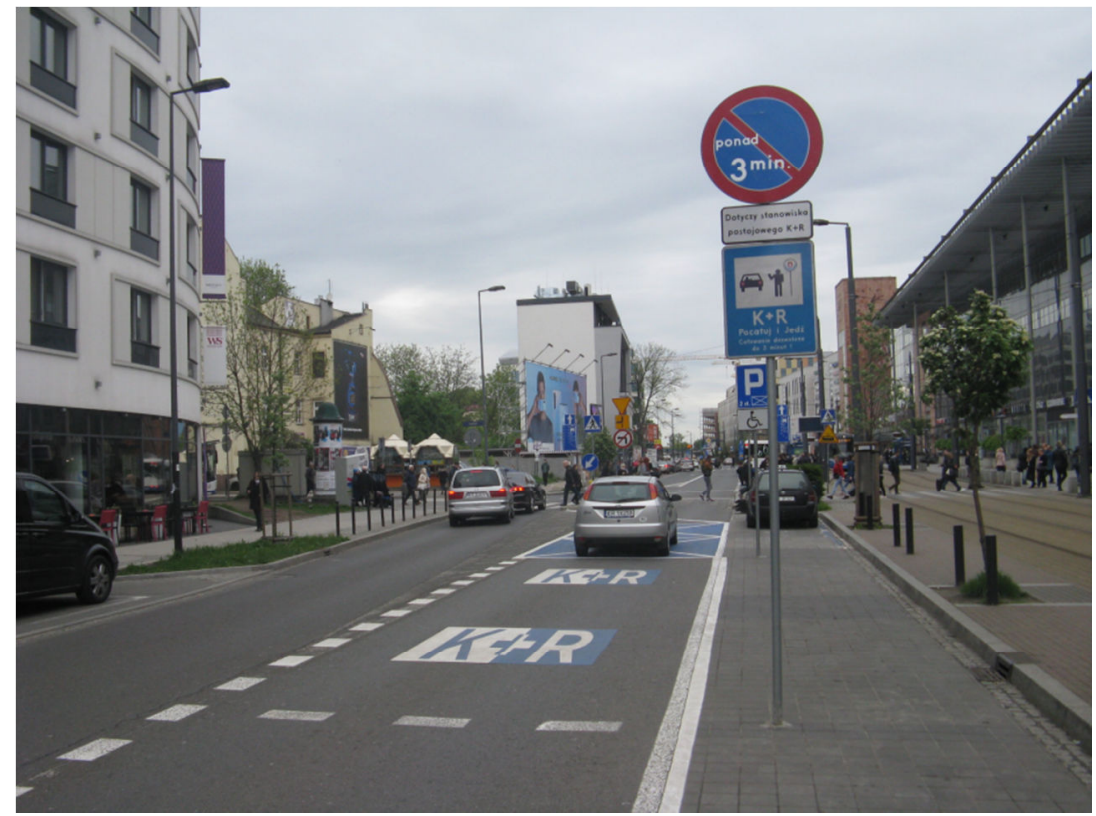

4. Kiss \& Ride car park in Kraków marking

In Warsaw, Kiss \& Ride car parks have been operating since 2016. The marking consists of a B-35 sign with information about the permitted parking time (usually 2 minutes). There is a sign under the sign that the sign applies to $\mathrm{K}+\mathrm{R}$ parking spaces and a color pictogram of the Kiss \& Ride zone. The marking is supplemented with a colored pictogram on the road. An example of marking the Kiss \& Ride car park in Warsaw is presented in Fig. 5. A similar method of marking is also used in Chorzów and Rybnik. 


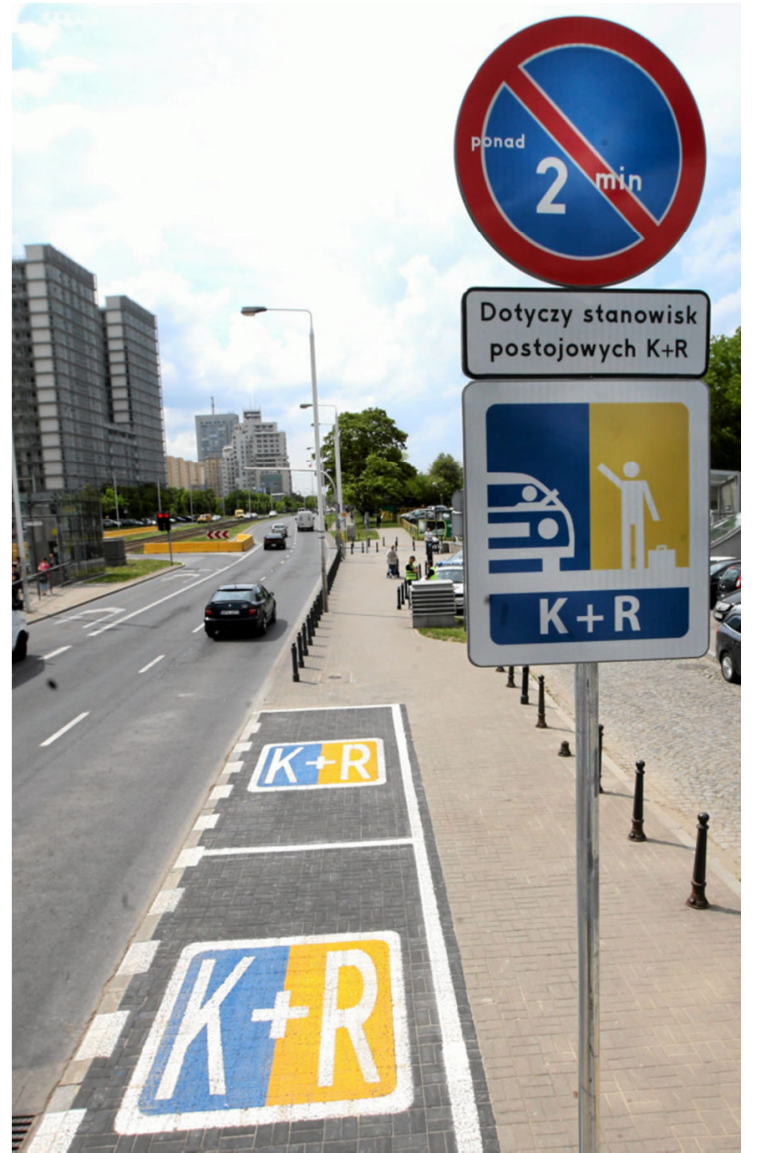

5. Kiss \& Ride car park in Warsaw marking[18]

In Szczecin, the marking of Kiss \& Ride car parks is marked with the D - 18 "parking" sign with an additional $\mathrm{K}+\mathrm{R}$ symbol. Under the sign, there is a plate with the information that it is a Kiss \& Ride car park and the permitted parking time (up to 1 minute). Parking spaces are also marked on the road with a white $K+R$ sign. An example of marking the Kiss \& Ride car park in Szczecin is shown in Fig. 6.

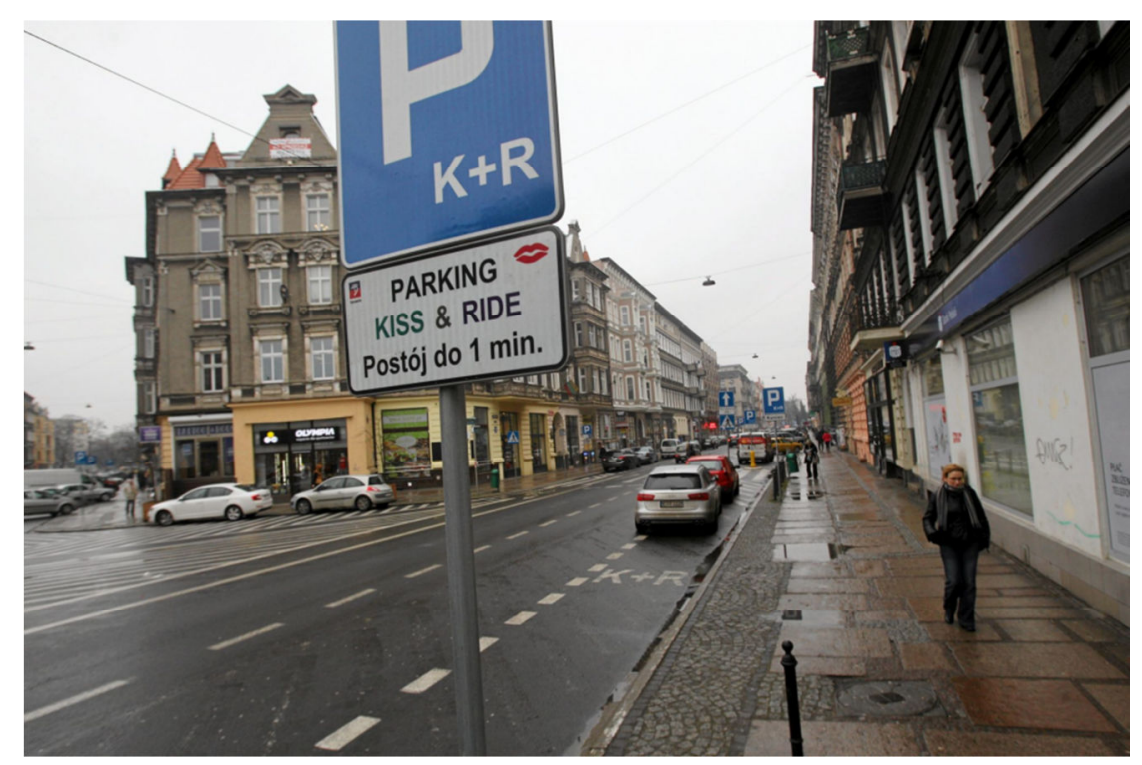

6. Kiss \& Ride car park marking in Szczecin [17] 


\section{Parking test method}

In order to evaluate the use of Kiss \& Ride car parks, traffic measurements were carried out. Four car parks located in the central part of Wrocław were selected for traffic analysis:

- P1 car park - located at Jana Ewangelisty Purkyniego Street at the Radisson Blu Hotel and Panorama Racławicka (Fig. 2),

- P2 car park - located at Kaziemierza Wielkiego Street in the area of the Nowe Horyzonty cinema,

- P3 car park - located at Sądowa Street,

- P4 car park - located at Joannitów Street near the Wroclavia shopping center, the POLBUS bus station and the railway station (Wrocław Główny).

The location of individual car parks is presented in Fig. 7. Table 1 shows the characteristics of individual car parks. There are currently eleven Kiss \& Ride car parks in Wrocław. The parking system is free of charge. The selection of only four Kiss \& Ride car parks in Wrocław was dictated by the pilot nature of the research. Such car parks were selected so that they differ in the time of permitted parking, the possibility of changing to public transport in the city, and the possibility of changing to railway transport. All analyzed car parks are located in the paid parking zone in Wrocław.

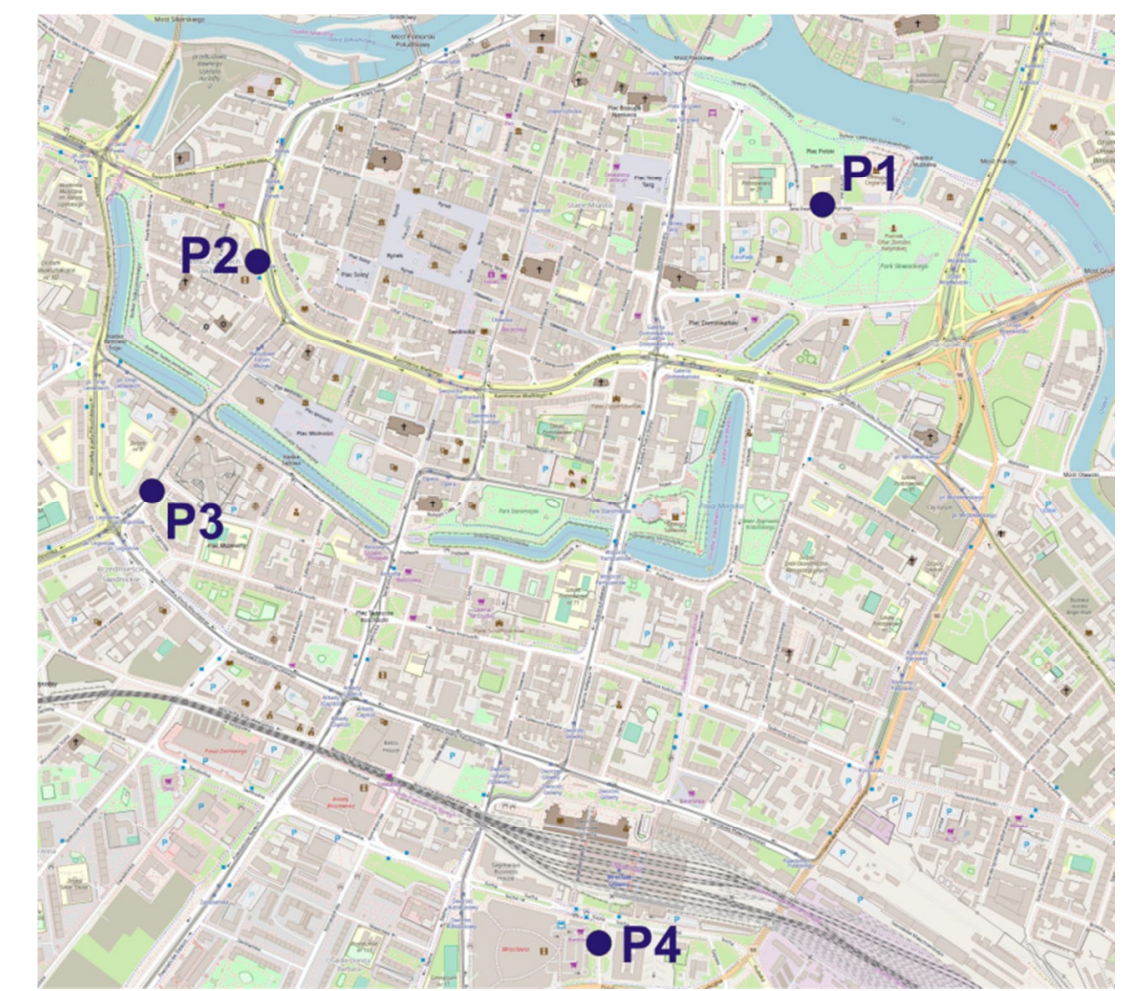

7. Location of car parks where traffic measurements were made [16] 
Tab. 1. Characteristics of particular car parks

\begin{tabular}{|l|l|l|l|l|}
\hline Car park & P1 & P2 & P3 & P4 \\
\hline $\begin{array}{l}\text { Pecation } \\
\text { time }\end{array}$ & $\begin{array}{l}\text { Purkyniego } \\
\text { Sreet }\end{array}$ & $\begin{array}{l}\text { Kazimierza } \\
\text { Wielkiego } \\
\text { Sreet }\end{array}$ & Sądowa Sreet & $\begin{array}{l}\text { Joannitów } \\
\text { Sreet }\end{array}$ \\
\hline $\begin{array}{l}\text { The number of Kiss \& } \\
\text { Ride parking spaces }\end{array}$ & 4 & 5 minutes & 15 minutes & 5 minutes \\
\hline $\begin{array}{l}\text { The possibility of } \\
\text { switching to public } \\
\text { transport no }\end{array}$ & 6 & 9 & 5 \\
\hline
\end{tabular}

Parking measurements were carried out in October and November 2018. In each place, measurements were taken once during the morning rush $\left(7^{00} \mathrm{AM} \div 9^{00} \mathrm{AM}\right)$ and the afternoon rush $\left(3^{00} \mathrm{PM} \div 5^{00} \mathrm{PM}\right)$ on the same day (Wednesday or Thursday). Measurements during the morning rush are marked with the letter "R", measurements during the afternoon rush are marked with the letter "P". Measurements were limited to only the two peak periods to observe differences in goals and stop times during the morning and afternoon peaks. The adopted measurement hours correspond to the communication peaks in Wrocław.

Measurements were started 15 minutes earlier before these periods to also observe the arrival of vehicles that had already departed during the two peak hours analyzed. The measurements were also terminated 15 minutes later to capture the end of a stoppage of vehicles arriving at the end of the measurement period (shortly before $9^{00} \mathrm{AM}$ or $5^{00} \mathrm{PM}$ ). In fact, the measurements lasted 2.5 hours each time. Only those vehicles that were parked in the adopted measurement period $\left(7^{00} \mathrm{AM} \div 9^{00} \mathrm{AM}\right.$ and $\left.3^{00} \mathrm{PM} \div 5^{00} \mathrm{PM}\right)$ were included in the analyzes. Vehicles that arrived at the parking lot before 700 (or $3^{00} \mathrm{PM}$ ) and departed before $7^{00} \mathrm{AM}$ (or $3^{00} \mathrm{PM}$ ) were not taken into account. Vehicles that arrived after $9^{00} \mathrm{AM}$ or $5^{00} \mathrm{PM}$ were also not taken into account.

During the measurements, the vehicle arrival time, vehicle type (taxi), purpose of parking and departure time were recorded. The purpose of the stop was determined on the basis of observations. The vehicles were parked for the following purposes:

- lifting someone,

- picking up someone,

- stop to arrange various matters (e.g. using an ATM, shopping, using various service points, meeting another person, talking on the phone, asking how to get to a specific street),

- delivery of goods to the store.

\section{Test results analysis}

Table 2 shows the number of vehicles that were observed at each test stand. In some measurement sites, the parking time of all vehicles was not captured because their arrival or departure (or both arrival and departure) exceeded the adopted measurement time. During the morning rush, the car parks were empty before the measurements began. However, after 2.5 hours of measurement, some vehicles still used this parking lot, despite the significantly exceeded parking time. It was the same during the afternoon rush hour. During this period, before the measurements were started, there were already vehicles in the parking lot, so the time of their arrival was not established. This situation happened only in one parking lot - at Sądowa Street - P3, where the allowed stop was up to 15 minutes. 
Tab. 2. Number of vehicles using particular parking lots

\begin{tabular}{|l|l|l|l|l|l|l|l|l|}
\hline $\begin{array}{l}\text { Description of the } \\
\text { measurement site }\end{array}$ & P1-R & P1-P & P2-R & P2-P & P3-R & P3-P & P4-R & P4-P \\
\hline $\begin{array}{l}\text { Number of vehicles in the } \\
\text { parking lot prior to the start of } \\
\text { measurements (unknown } \\
\text { arrival time) }\end{array}$ & 0 & 0 & 0 & 0 & 0 & 6 & 0 & 0 \\
\hline $\begin{array}{l}\text { Number of vehicles in the } \\
\text { parking lot after completion of } \\
\text { the measurements (unknown } \\
\text { departure time) }\end{array}$ & 0 & 0 & 0 & 0 & 5 & 2 & 0 & 0 \\
\hline $\begin{array}{l}\text { Number of parking vehicles at } \\
\text { all times of measurement } \\
\text { (unknown arrival and departure } \\
\text { time) }\end{array}$ & 0 & 0 & 0 & 0 & 0 & 1 & 0 & 0 \\
\hline $\begin{array}{l}\text { Number of parking vehicles } \\
\text { with known arrival and } \\
\text { departure times }\end{array}$ & 13 & 13 & 31 & 35 & 17 & 10 & 27 & 33 \\
\hline Number of all vehicles & $\mathbf{1 3}$ & $\mathbf{1 3}$ & $\mathbf{3 1}$ & $\mathbf{3 5}$ & $\mathbf{2 2}$ & $\mathbf{1 9}$ & $\mathbf{2 7}$ & $\mathbf{3 3}$ \\
\hline
\end{tabular}

The number of vehicles using individual parking lots varied. The fewest vehicles were observed in the area of Panorama Racławicka (P1 car park), and the highest number in the area of transfer junctions (P2 and $\mathrm{P} 4$ car parks). The number of vehicles observed during the morning rush and the afternoon peak was similar.

Tab. 3. Characteristics related to the time of stop in car parks

\begin{tabular}{|l|l|l|l|l|l|l|l|l|}
\hline $\begin{array}{l}\text { Description the } \\
\text { measurement site }\end{array}$ & P1-R & P1-P & P2-R & P2-P & P3-R & P3-P & P4-R & P4-P \\
\hline Allowed stopping time [min] & 5 & 5 & 5 & 5 & 15 & 15 & 5 & 5 \\
\hline $\begin{array}{l}\text { Number of vehicles not } \\
\text { exceeding the allowed parking } \\
\text { time [P] }\end{array}$ & 6 & 8 & 25 & 23 & 15 & 7 & 13 & 20 \\
\hline $\begin{array}{l}\text { Percentage of vehicles not } \\
\text { exceeding the allowed parking } \\
\text { time [\%] }\end{array}$ & 46,2 & 61,5 & 80,6 & 65,7 & 68,2 & 36,8 & 48,1 & 60,6 \\
\hline $\begin{array}{l}\text { Number of vehicles exceeding } \\
\text { the allowed parking time [P] }\end{array}$ & 7 & 5 & 6 & 12 & 7 & 12 & 14 & 13 \\
\hline $\begin{array}{l}\text { Percentage of vehicles } \\
\text { exceeding the allowed parking } \\
\text { time [\%] }\end{array}$ & 53,8 & 38,5 & 19,4 & 34,3 & 31,8 & 63,2 & 51,9 & 39,4 \\
\hline Minimal stopping time [min] & 0,5 & 0,4 & 0,1 & 0,2 & 0,2 & 0,1 & 0,3 & 0,2 \\
\hline Maximum stopping time [min] & 48,9 & 120,1 & 38,0 & 82,9 & - & - & 40,3 & 145,2 \\
\hline Average stopping time [min] & 13,0 & 13,0 & 4,1 & 6,8 & - & - & 11,2 & 12,5 \\
\hline Quantile 25 \% [min] & 2,1 & 1,2 & 0,3 & 0,5 & - & - & 0,7 & 0,8 \\
\hline Median [min] & 5,3 & 1,9 & 0,7 & 1,9 & - & - & 5,5 & 2,4 \\
\hline Quantile 75 \% [min] & 23,2 & 8,8 & 4,5 & 6,3 & - & - & 17,9 & 6,8 \\
\hline Percentile 85 \% [min] & 31,2 & 12,7 & 6,5 & 12,1 & - & - & 32,3 & 17,2 \\
\hline
\end{tabular}


Table 3 presents the characteristics related to the parking time in individual car parks. All observed vehicles were included in the analyzes. Only in the P3 car park, the parking time of all vehicles was not measured. For this reason, some of the characteristics (average stop time, maximum stop time) were not defined).

In all analyzed parking lots, some of the vehicles exceeded the permitted parking time. The share of vehicles exceeding the permitted parking time ranged from $19,4 \div 63,2 \%$. The largest number of vehicles exceeding the permitted parking time was observed in car park P3 in the afternoon peak. Almost two-thirds of the vehicles exceeded the allowed parking time (15 minutes), and the drivers of these vehicles treated this Kiss \& Ride car park as free parking.

The minimum stopping time was quite low - in individual parking lots, it ranged from $0,1 \div 0,5$ minutes. This time depended on the purpose of the stop:

- when lifting a passenger -8 seconds,

- when picking up the passenger -19 seconds,

- when delivering to the store - 3,2 minutes,

- when stopping to arrange the matter -25 seconds.

On the other hand, the maximum stopping time in car parks with a permitted parking time of up to 5 minutes was:

- almost 2.5 hours at the P4 car park (145 minutes),

- 2 hours in the P1 car park,

- almost an hour and a half in the P2 car park (83 minutes).

The average time of parking in these car parks was respectively: 13 minutes (P1 car park), 5.5 minutes (P2 car park) and 12 minutes (P4 car park). In these car parks, the stop of half the vehicles (median) did not exceed 5.3 minutes (P1 car park), 1.9 minutes (P2 car park), and 5.5 minutes (P4 car park). Histograms of the distribution of parking times in individual car parks are presented in Fig. $\mathbf{8} \div \mathbf{1 1}$.

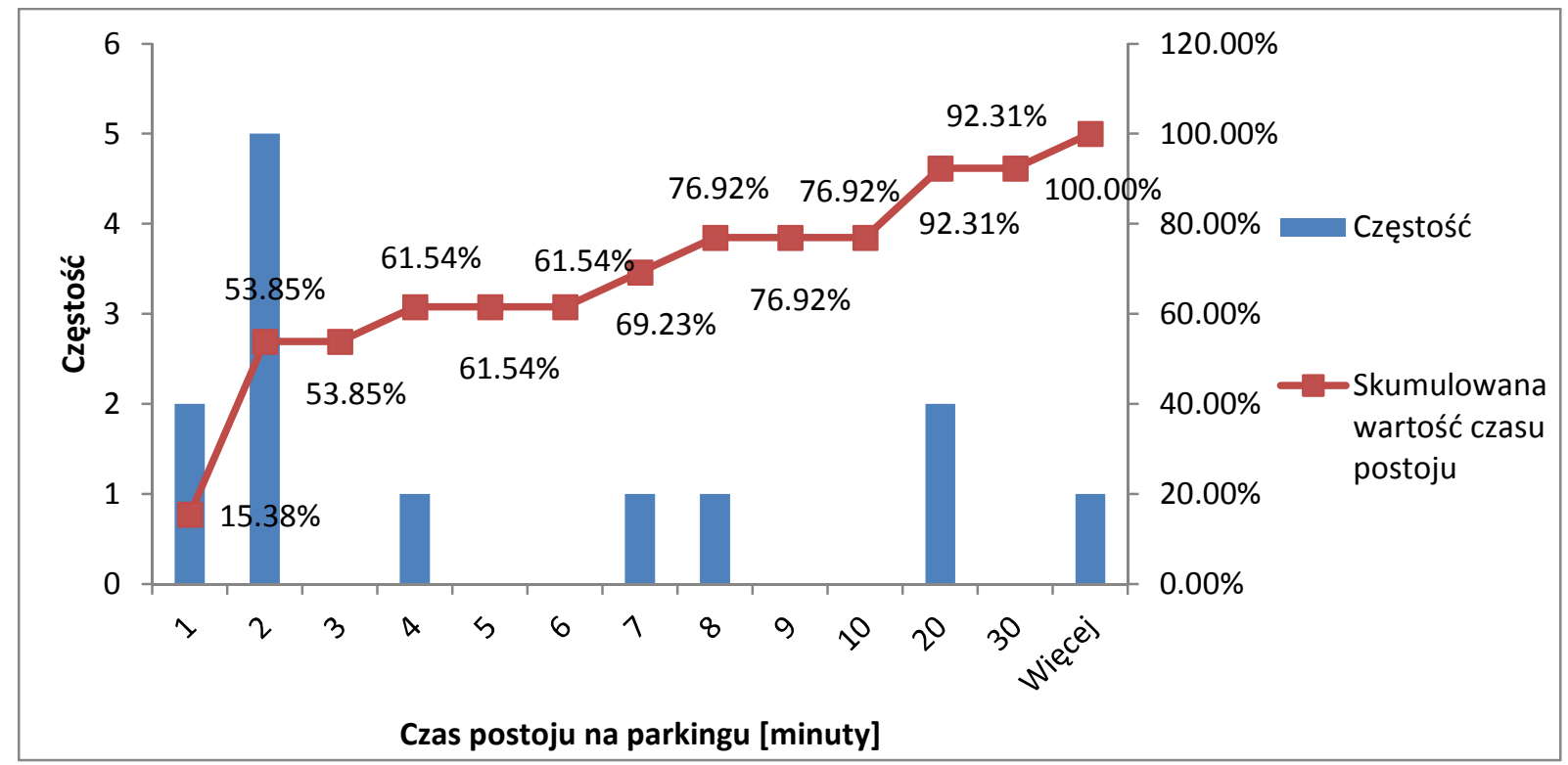

8. Histogram of the distribution of stopping time in car park P1 during the afternoon rush hours (P1-P) 


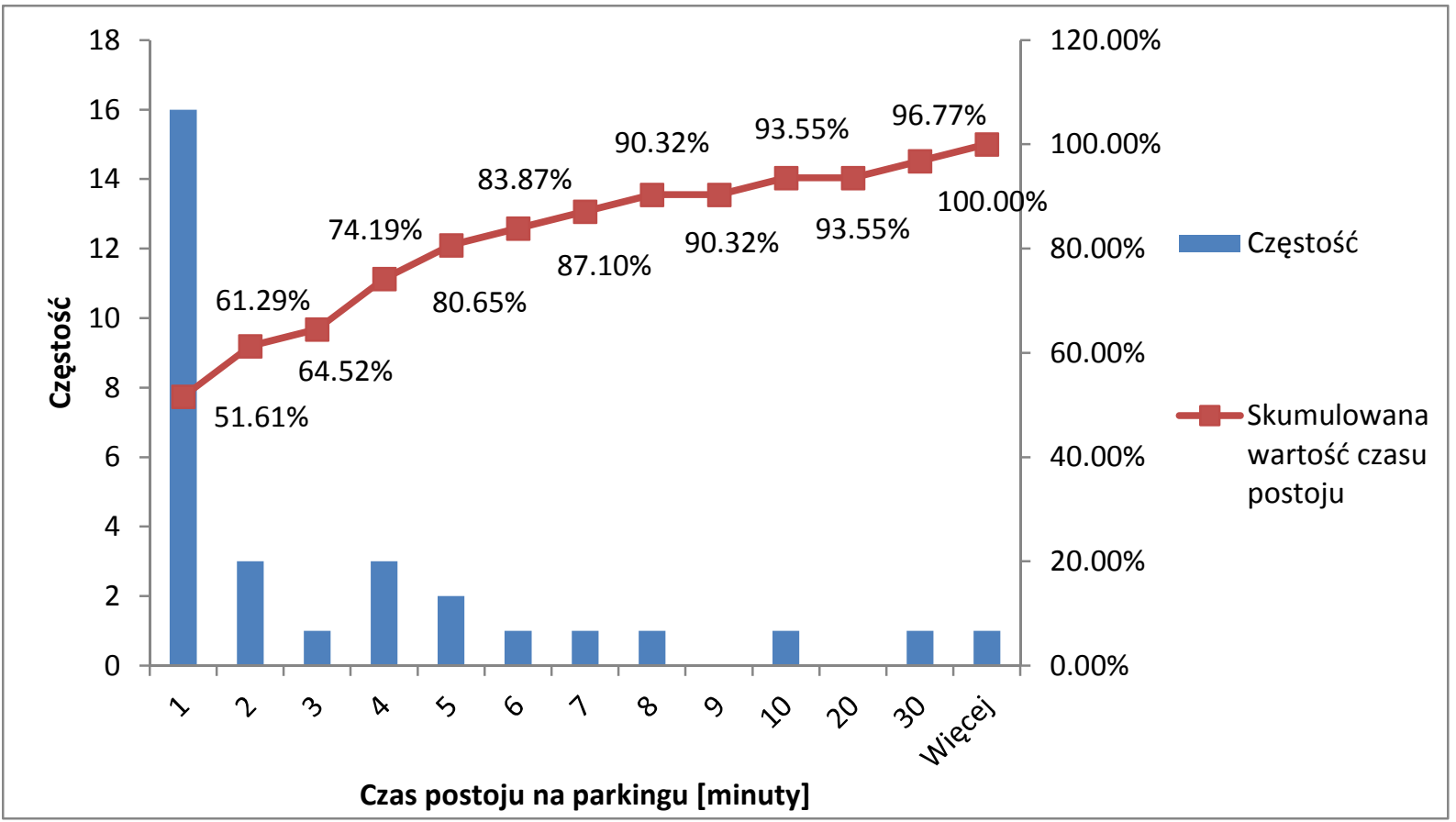

9. Histogram of stopping time distribution in parking lot $\mathrm{P} 2$ during the morning rush hours (P2-R)

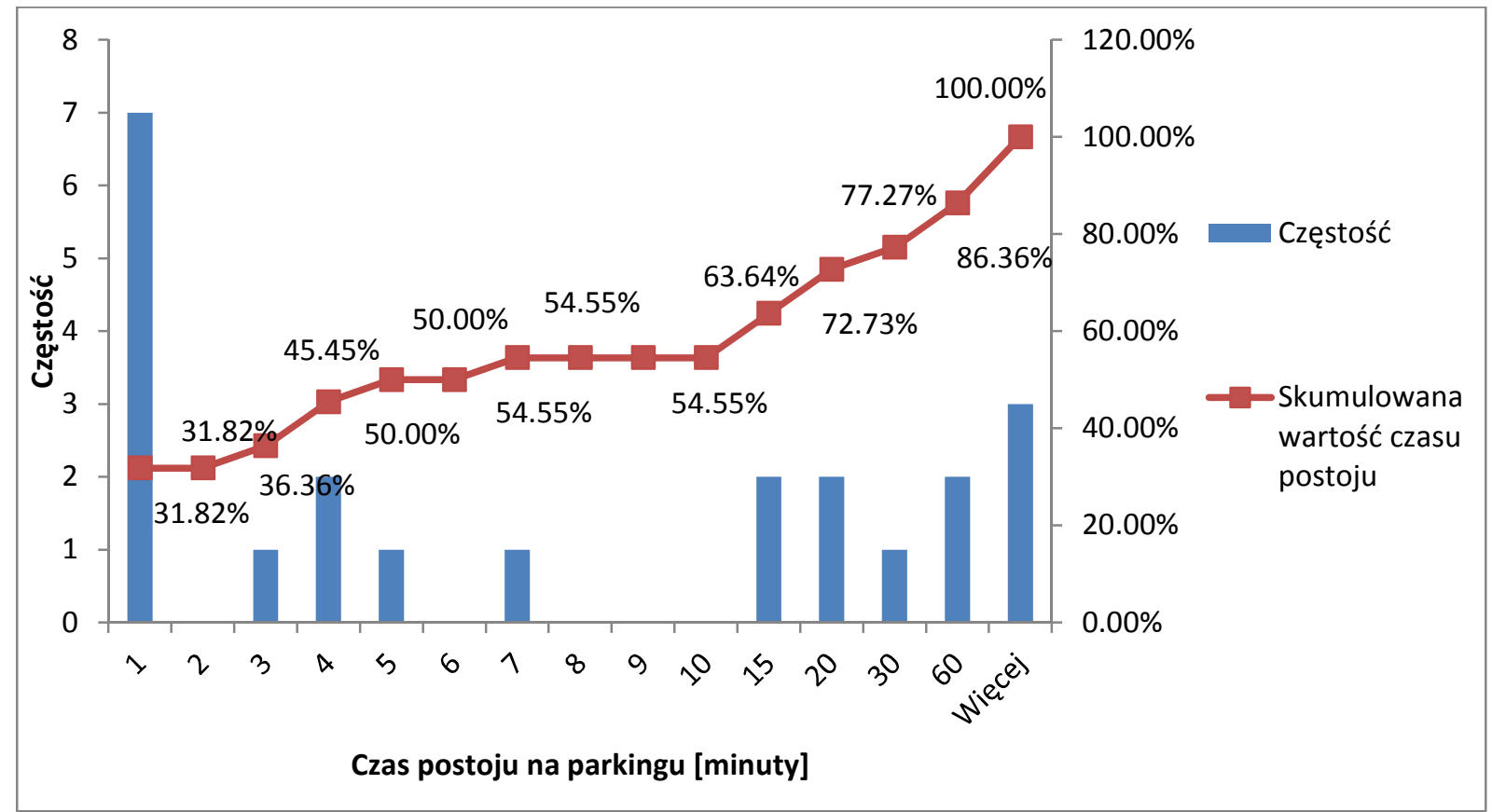

10. Histogram of the distribution of stopping time in the $\mathrm{P} 3$ car park during the morning rush hours (P3-R) 


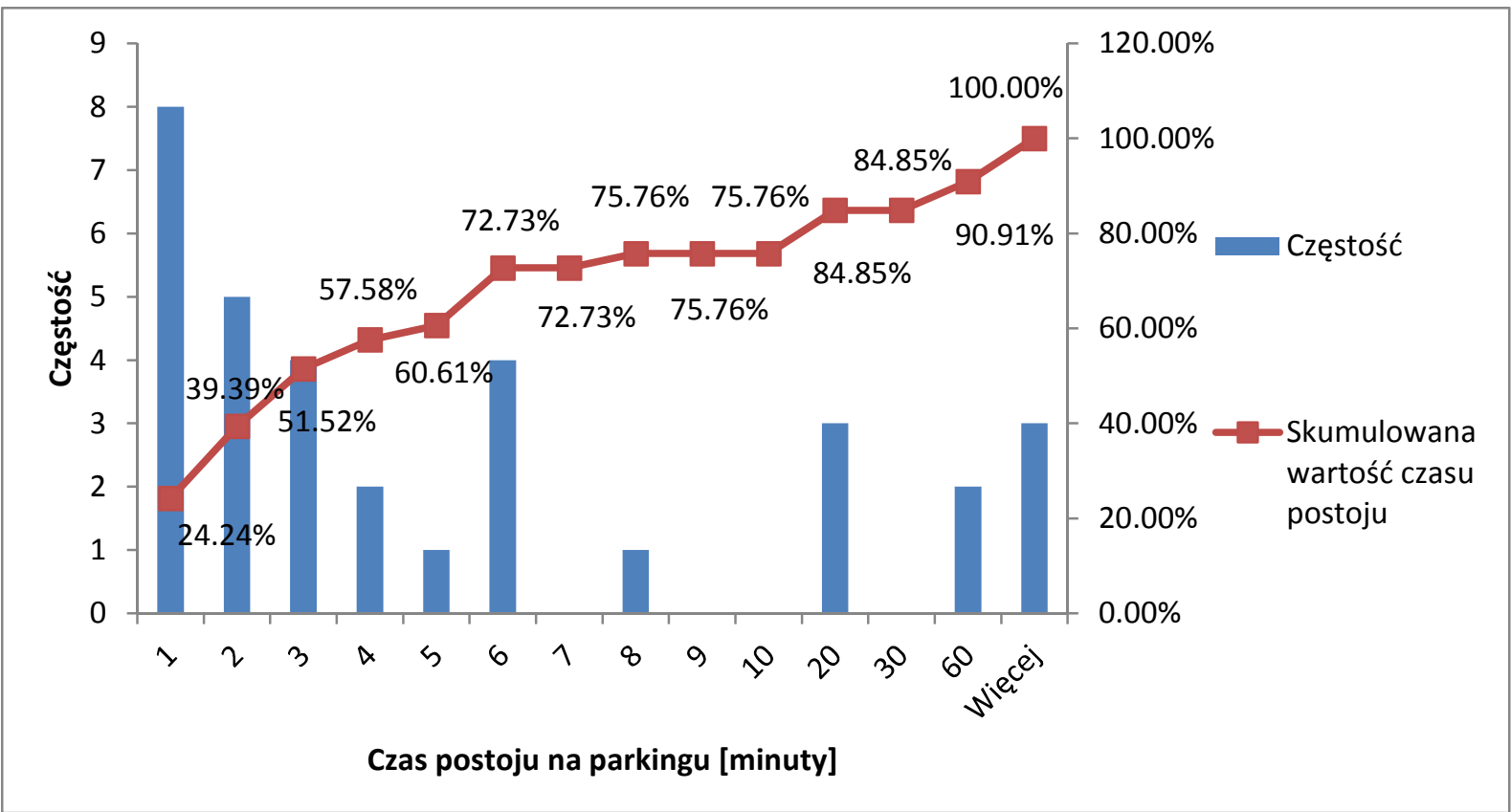

11. Histogram of the distribution of stopping time in car park $\mathrm{P} 4$ during the afternoon rush hours (P4-P)

It was also observed that the average time of parking vehicles in the parking lot in the area of public transport stops in the city (parking P2) is $2 \div 3$ times shorter than the stopping time in the area of Wrocław Główny railway station (parking P4).

Table 4 presents the characteristics related to the use of parking lots. The individual parameters were calculated on the basis of [6]. The rotation index was calculated for the twohour period in which the traffic measurements were performed. The lowest turnover rate was recorded in car park P3. During the morning peak, it was 2.4, during the afternoon peak it was 2.1. In the car park $\mathrm{P} 1$, the turnover ratio was 3.3 during both peaks. On the other hand, the highest turnover rate was observed in car parks P2 and P4, located in the area of interchange nodes. In these car parks, the turnover ratio was $5.2 \div 6.6$.

Tab. 4. Characteristics related to the use of car parks

\begin{tabular}{|l|l|l|l|l|l|l|l|l|}
\hline $\begin{array}{l}\text { Description of the } \\
\text { measurement site }\end{array}$ & P1-R & P1-P & P2-R & P2-P & P3-R & P3-P & P4-R & P4-P \\
\hline Rotation rate within 2 hours & 3,3 & 3,3 & 5,2 & 5,8 & 2,4 & 2,1 & 5,4 & 6,6 \\
\hline Average accumulation [P] & 1,2 & 1,4 & 1,1 & 1,9 & 3,8 & 4,8 & 2,3 & 4,0 \\
\hline $\begin{array}{l}\text { Average rate of the use of } \\
\text { parking space [\%] }\end{array}$ & 30 & 35 & 18 & 32 & 42 & 53 & 46 & 80 \\
\hline
\end{tabular}

Figs. $12 \div 15$ present graphs showing the use of parking spaces in car parks during the two-hour traffic measurements. The average accumulation of vehicles ranged from 1.1 to 4.8 vehicles. The highest average accumulation occurred in the P3 car park. During the morning rush hour, there was an average of 3.8 cars parked in the car park, while in the afternoon rush hour, there were 4.8 cars parked in the car park.. 

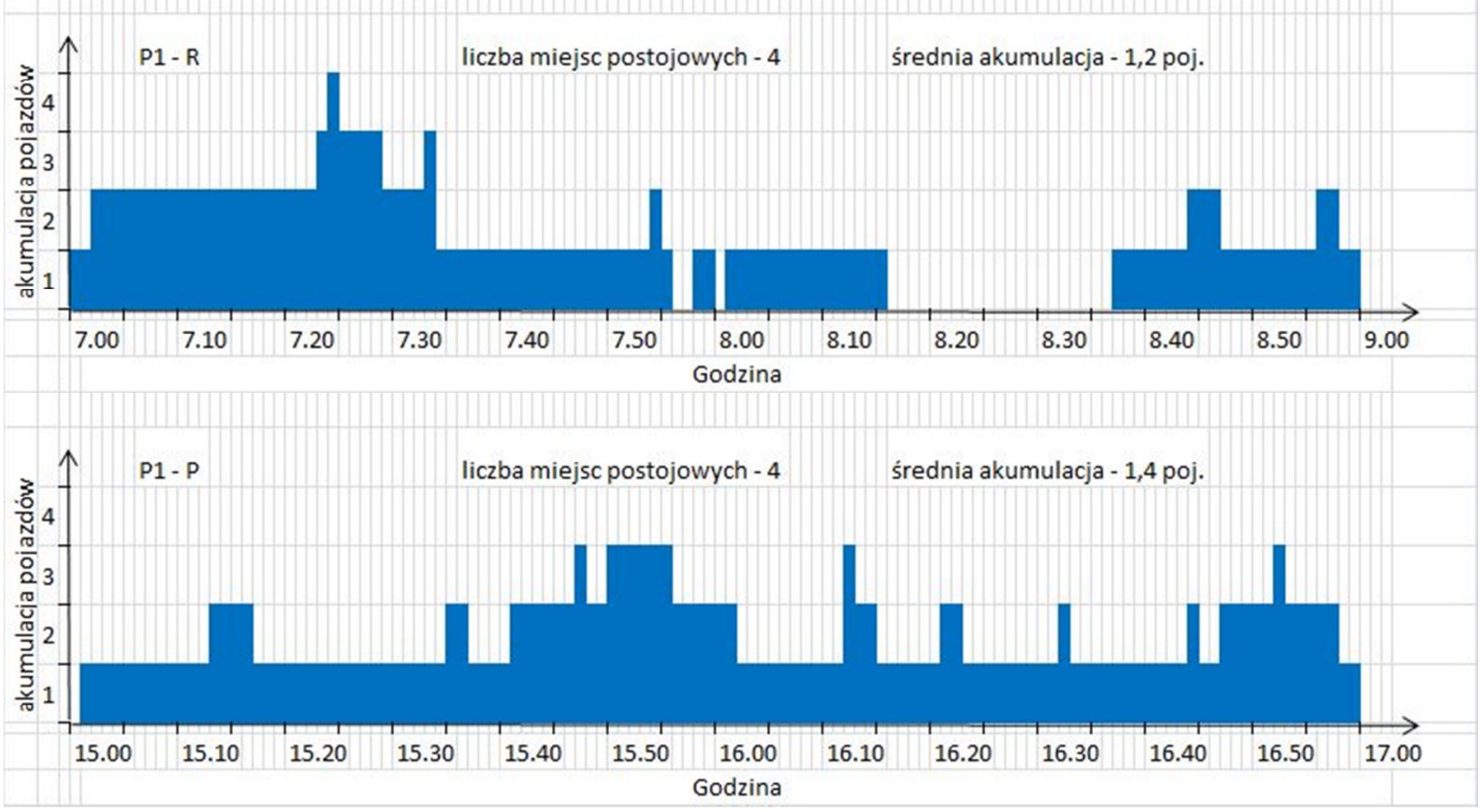

12. Accumulation of vehicles in the P1 car park

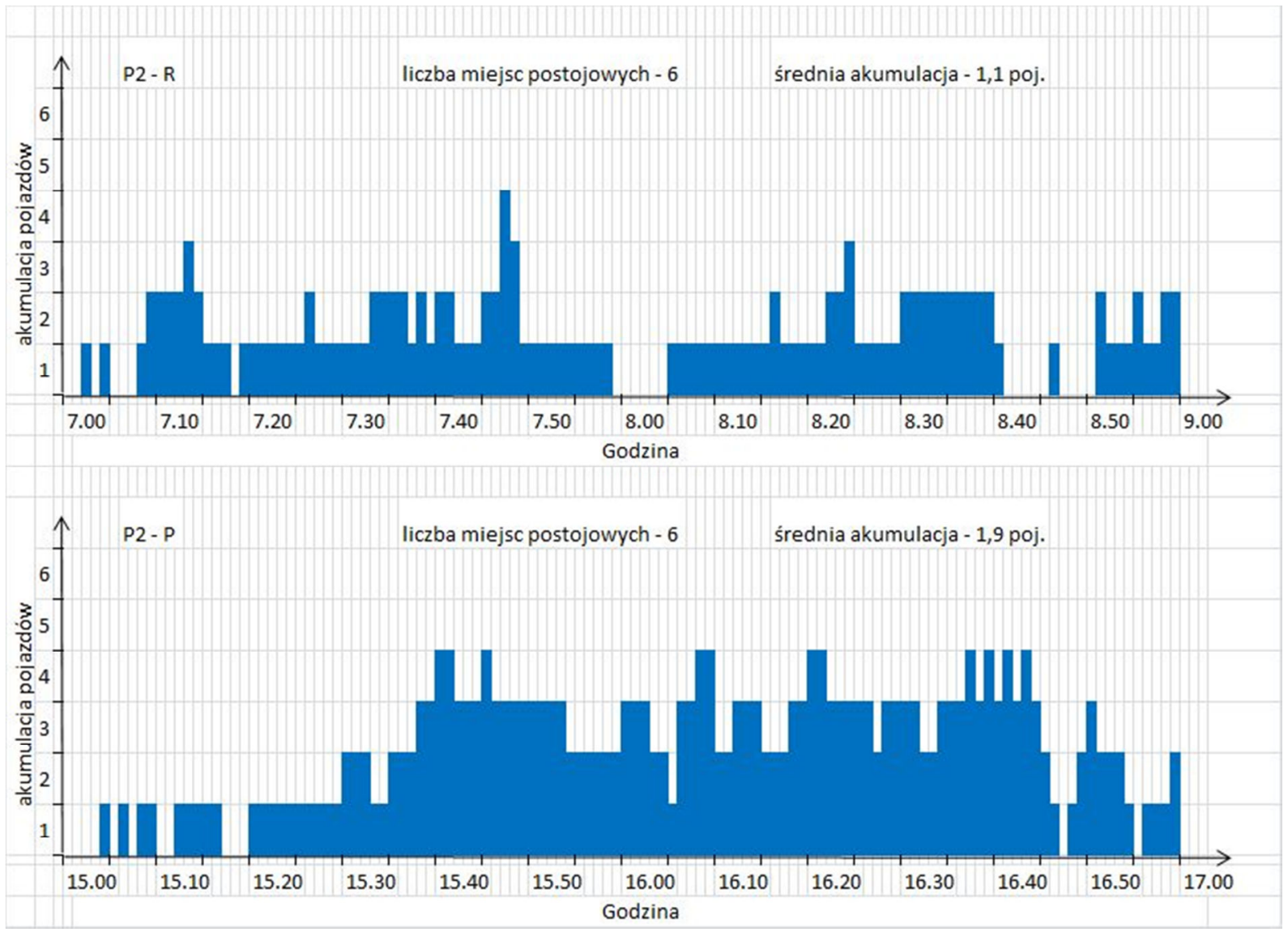

13. Accumulation of vehicles in parking lot $\mathrm{P} 2$ 


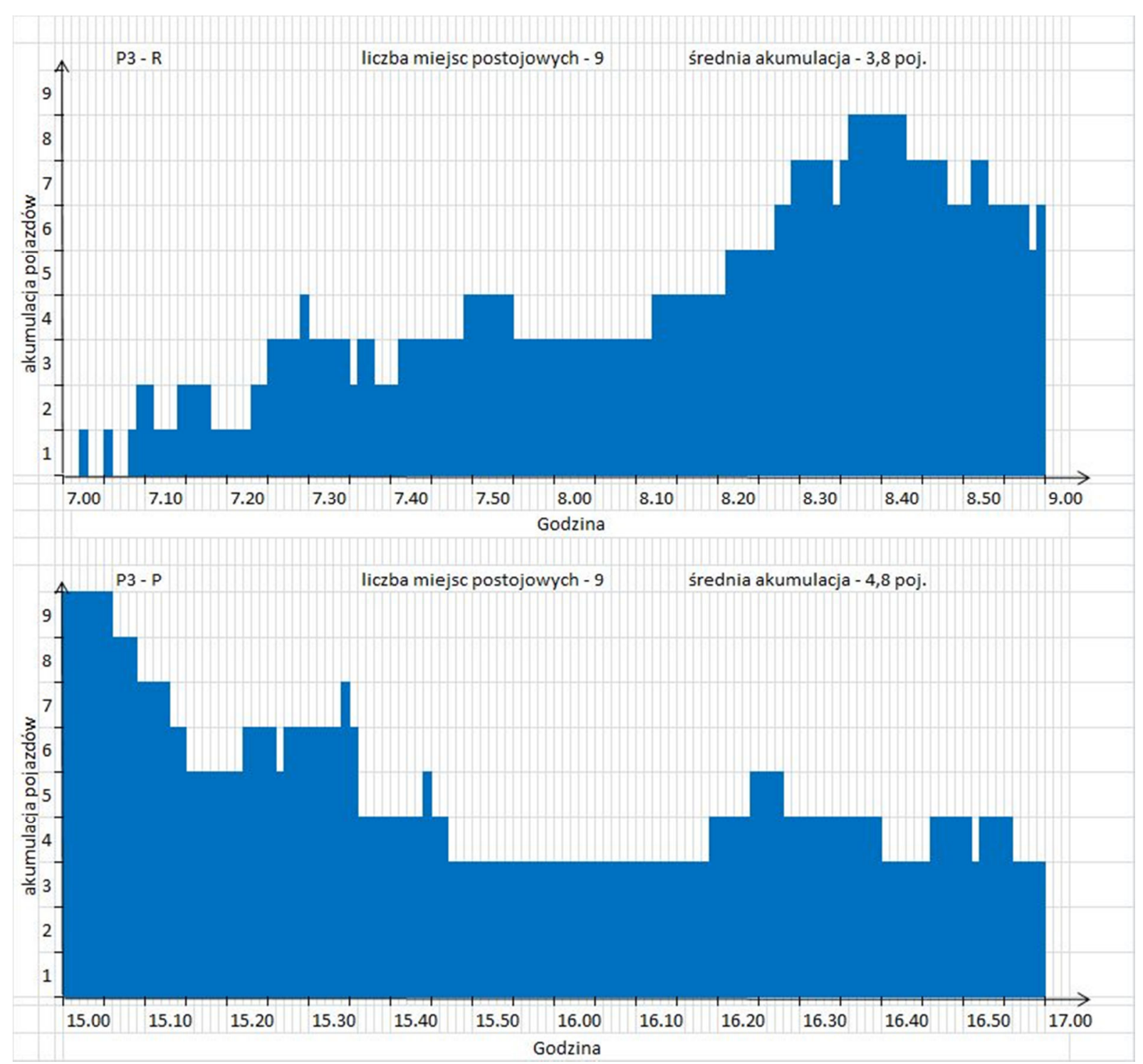

14. Accumulation of vehicles in the $P 3$ car park 


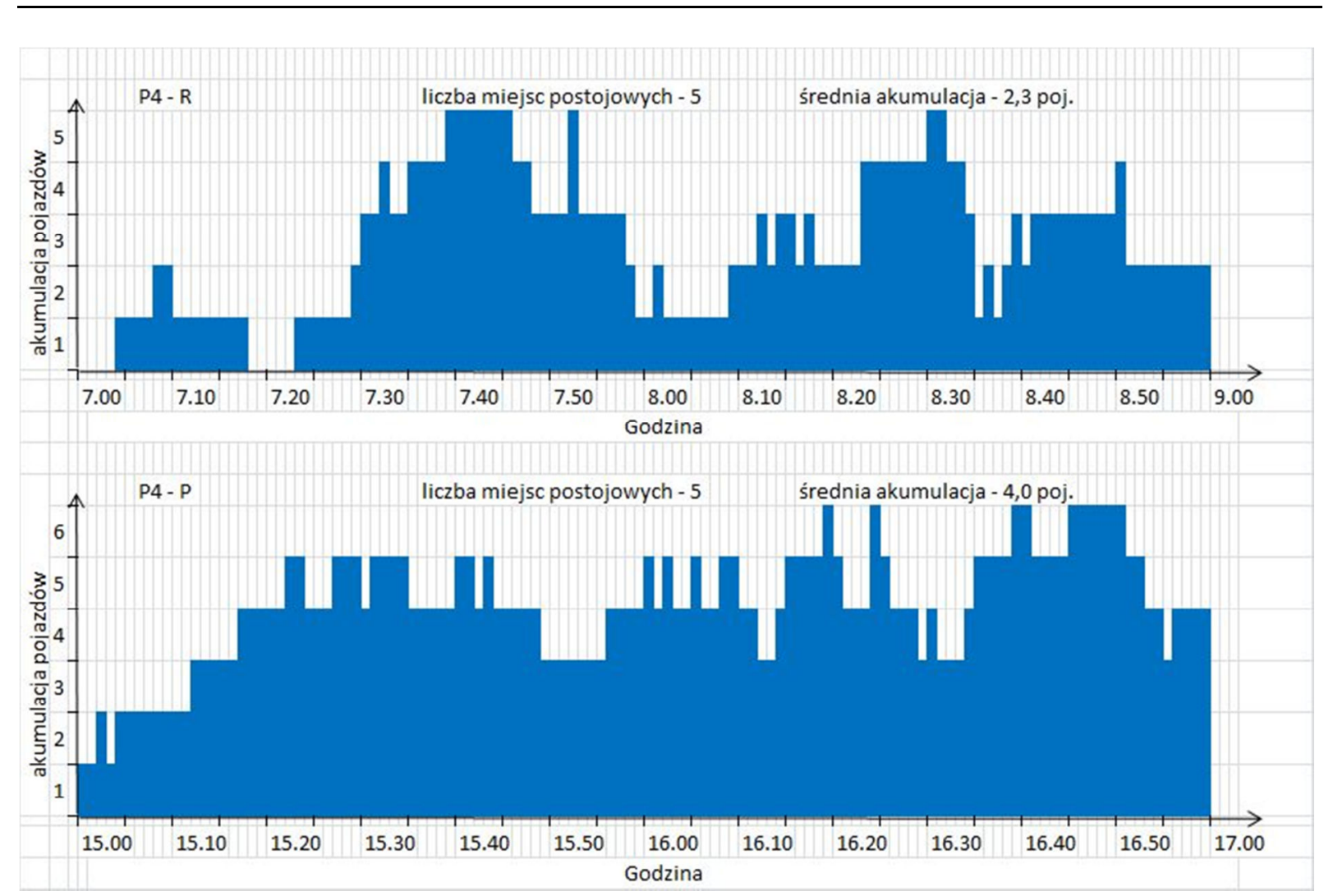

15. Accumulation of vehicles in the $\mathrm{P} 4$ car park

The average indicator of the use of parking space was also determined. It fluctuated between $18 \%$ and $80 \%$. The smallest rate occurred in parking lot P2 during the morning rush hours. The highest indicator was recorded in the $\mathrm{P} 4$ car park during the afternoon rush hours. Four times the capacity of the parking space was exceeded in this car park. Due to the fact that all parking spaces were occupied in the Kiss \& Ride car park, subsequent vehicles stopped on the road, thus blocking the traffic on the road. During the measurements, the purpose of parking in the Kiss \& Ride car parks was also observed. The percentages of parking goals are presented in Table 5. In the car parks with a parking time allowed up to 5 minutes, it was dominated by picking up and picking up other people, and in a car park with a parking time of up to 15 minutes, parking to arrange the matters was dominant. In each analyzed place, the share of vehicles whose drivers left the vehicle in the parking lot to arrange the matters was additional during the afternoon rush than during the morning rush. In the area of interchange nodes (car parks P2 and P4), during the morning rush hours, $55 \%$ and $45 \%$ of drivers using the car park, respectively, picked up another person. During the afternoon rush hours, the share of drop offs and pick-ups was similar $(34.3 \%$ and $37.1 \%$ in P2 parking, and $33.3 \%$ and $30.3 \%$ in $\mathrm{P} 4$ parking). In contrast, deliveries to stores were much greater during the morning rush hours. The use of Kiss \& Ride car parks by taxis was also observed during the research. The results are presented in Table $\mathbf{6}$.

Tab. 5. Percentage of parking purposes in the analyzed Kiss \& Ride car parks

\begin{tabular}{|l|l|l|l|l|l|l|l|l|}
\hline Purpose of the stop & P1-R & P1-P & P2-R & P2-P & P3-R & P3-P & P4-R & P4-P \\
\hline Passenger lift [\%] & 0,0 & 38,5 & 54,8 & 34,3 & 22,7 & 0,0 & 44,5 & 33,3 \\
\hline Passenger pickup [\%] & 100 & 46,1 & 16,1 & 37,1 & 9,1 & 15,8 & 18,5 & 30,3 \\
\hline $\begin{array}{l}\text { Stop for arranging various } \\
\text { matters [\%] }\end{array}$ & 0,0 & 15,4 & 6,5 & 22,9 & 59,1 & 78,9 & 29,6 & 36,4 \\
\hline $\begin{array}{l}\text { Delivery of goods to the store } \\
{[\%]}\end{array}$ & 0,0 & 0,0 & 22,6 & 5,7 & 9,1 & 5,3 & 7,4 & 0,0 \\
\hline
\end{tabular}


Tab. 6. Use of Kiss \& Ride car parks by taxis

\begin{tabular}{|l|l|l|l|l|l|l|l|l|}
\hline $\begin{array}{l}\text { Description of the } \\
\text { measurement site }\end{array}$ & P1-R & P1-P & P2-R & P2-P & P3-R & P3-P & P4-R & P4-P \\
\hline $\begin{array}{l}\text { Number of taxis using car } \\
\text { parks [P] }\end{array}$ & 9 & 6 & 6 & 6 & 0 & 0 & 10 & 10 \\
\hline Percentage of taxis [\%] & 69,2 & 46,2 & 19,4 & 17,1 & 0,0 & 0,0 & 37,0 & 30,3 \\
\hline $\begin{array}{l}\text { Number of taxis picking up the } \\
\text { passengers [P] }\end{array}$ & 9 & 3 & 1 & 4 & 0 & 0 & 1 & 4 \\
\hline $\begin{array}{l}\text { Number of taxis lifting the } \\
\text { passengers [P] }\end{array}$ & 0 & 3 & 4 & 2 & 0 & 0 & 6 & 3 \\
\hline $\begin{array}{l}\text { Number of taxis that have not } \\
\text { lifted or picked up anybody [P] }\end{array}$ & 0 & 0 & 1 & 0 & 0 & 0 & 3 & 3 \\
\hline
\end{tabular}

The share of taxis using the Kiss \& Ride car parks was significant, especially in the area of hotels (P1 car park), where in the morning it reached $69 \%$ of all vehicles using the car park. There was also a very large share in the area of the long-distance communication station (parking lot P4). During the morning rush hours, the share of taxis was $37 \%$ of all vehicles using the car park, while during the afternoon rush hours, the share of taxis was $30.3 \%$.

In the hotel area (car park P1) pick-up was dominant during the morning rush. However, during the afternoon rush hours, an equal number of taxis bringing people to the hotel and those picking up from the hotel was observed.

In the area of interchange junctions, during the morning rush, passengers were mostly picked up. During the afternoon rush hours, the share of people who were given a lift was smaller than the share of people picked up by taxis.

It was also noted that the Kiss \& Ride car park was used as a taxi stand. The taxi driver neither lifted any passenger nor picked up another. The parking lot was a free place where the taxi driver waited for the next route. Such a taxi stop took place in the car park near the Main Railway Station (P4 car park). Three such vehicles were observed at each peak, accounting for $30 \%$ of all taxi users. The stopping times were respectively 16, 12, and 39 minutes for the morning rush and 38, 4, 84 minutes for the afternoon rush..

\section{Summary}

Kiss \& Ride car parks are very popular in the world, especially in highly developed countries $[4,5]$, just like Park \& Ride car parks [10, 12, 13] or Bike \& Ride car parks [7]. Although Kiss \& Ride car parks are very popular, in most countries they have not yet had a separate label with which they should be marked. For several years, Kiss \& Ride car parks have also been introduced to Polish cities. This does not mean that the idea was not known before. In many cities, there were short-term parking zones, although they were not called Kiss \& Ride zones or parking lots. Now, thanks to special markings, they are easier to read and notice by drivers. The technical conditions [11] do not introduce a new sign on the Kiss \& Ride car park marking, but they tell how to mark areas intended for short-term parking (using the sign B35). For this reason, the marking of Kiss \& Ride parking lots is different in each city. There are also situations where different car parks of this type in one city are marked differently (e.g. in Wrocław).

The idea of Kiss \& Ride car parks is that they should be located in the vicinity of transfer junctions and allow for lifting or picking up other people using public transport. Thanks to this solution, travelers are encouraged to travel by public transport. Indeed, as shown by the parking research carried out in Wrocław, in Kiss \& Ride car parks located close to transfer junctions, the dominant purpose of parking was to pick up or pick up other people. 
Car parks of this type also served as a parking space for cars to deliver goods to the store (delivery vans, but also SUVs and combi cars). They were also used to park vehicles, where the vehicle driver stopped, dealt with various matters inside the car (talking on the phone, looking for a road, street) or near the parking lot (using an ATM, making small purchases, using various service points). The parking lots were also used by taxi drivers as a free place where they could wait for the next route.

Kiss \& Ride car parks in Wrocław are located not only in the area of transfer nodes but also near other places where there is a need to lift or pick up other people (e.g. in the area of hotels, tourist attractions).

The parking research carried out at four Kiss \& Ride car parks in Wrocław showed that the permitted parking time was not respected in any of these car parks. In Wrocław, the allowed parking time is 5 or 15 minutes. The longer the permitted parking time was, the more drivers treated the Kiss \& Ride car park as a curb-side car park, and free of charge. The maximum observed downtime was almost 2.5 hours (145 minutes). The car parks were also used by vehicles for which neither the time of arrival nor the time of departure was observed during the measurements (their stop was longer than 2.5 hours, during which the traffic tests were carried out). The share of vehicles whose parking was longer than the allowed 5 or 15 minutes ranged from 19\% (P2 car park during the morning rush hour) to 63\% (P3 car park during the afternoon rush hour).

Kiss \& Ride car parks are a new solution in Polish cities, but they are very popular. During the two hours of measurement, $13 \div 35$ vehicles stopped at each of the observed parking lots in Wrocław. Hopefully, drivers of vehicles using these parking lots will learn to respect the allowed parking times so that other drivers in need can also benefit from these parking lots.

The benefits of Kiss \& Ride car parks should encourage road managers in other cities (not only the largest ones) to use such car parks in other cities. Thanks to this solution, it is possible to increase the number of people traveling in individual cars and to increase the number of journeys made by public transport. The inclusion of new parking solutions (Kiss \& Ride, Park \& Ride, Bike \& Ride) in the applicable legal requirements will also contribute to the fact that all parking lots of this type in Poland will be marked equally.

The parking research carried out in four selected Kiss \& Ride car parks in Wrocław was of a pilot nature. Their main purpose was to check compliance with the permitted parking time and the purpose of parking. For this reason, car parks with different characteristics were selected (different parking times, the possibility of changing to public transport, the possibility of changing to rail transport, the presence of a hotel). Based on one-off measurements, conclusions cannot be generalized to all such solutions in the country. It is necessary to conduct more extensive parking research, including, first of all, repeated traffic tests in one measurement place, a longer measurement period (preferably a continuous measurement period, e.g. 12 hours to capture the parking time of all parked vehicles), taking into account a larger number of parking lots and tests in different cities in Poland.

\section{Source materials}

[1] Bekhar S., Shiftan Y. Specification and estimation of mode choice model capturing similarity between mixed auto and transit alternatives. Journal of Choice Modelling no. 3 (2), str. $29-49$

[2] Bełch P. Analiza założeń koncepcji integracji transportu zbiorowego z indywidualnym. Modern Management Review, vol. XX no. 2/2015, str. 7 - 14

[3] Duda U. Analiza funkcjonowania strefy kiss and ride przy Małopolskim Dworcu Autobusowym w Krakowie. Transport Miejski i Regionalny, nr 2/2015, str. 14 - 18 
[4] Duda U. Przegląd stosowanego w wybranych krajach oznakowania stref kiss and ride. Transport Miejski i Regionalny, nr 1/2015, str. 3 - 8

[5] Duda U., Starowicz W. Strefy krótkiego postoju kiss and ride. Transport Miejski i Regionalny, nr 12/2014, str. 18 - 24

[6] Gaca S., Suchorzewski W., Tracz M. Inżynieria ruchu drogowego. Teoria i praktyka. Wydawnictwa Komunikacji i Łączności. Warszawa 2008

[7] Gasz K., Kruszyna M. Propozycja wprowadzenia systemu „Bike and Ride” do polskich miast na przykładzie Wrocławia. Transport Miejski i Regionalny, nr 6/2005, str. 30 - 33

[8] Hasnine M. S., Habib K. N. What about the dynamics in daily travel mode choices? A dynamic discrete choice approach for tour - based mode choice modelling. Transport Policy no. 71 (2018), str. $70-80$

[9] Hasnine M. S., Lin T., Weiss A., Habib K. N. Determination of travel mode choices of post-secondary students in a large metropolitan area: The case of the city of Toronto. Journal of Transport Geography no. 70 (2018), str. 161 - 171

[10] Kasperczak K. Parkuj i Jedź przyjazny niepełnosprawnym. Przegląd Komunikacyjny, nr 1/2014, str. $6-11$

[11] Rozporządzenie Ministra Infrastruktury $\mathrm{z}$ dnia 3 lipca 2003 roku $\mathrm{w}$ sprawie szczegółowych warunków technicznych dla znaków i sygnałów drogowych oraz urządzeń bezpieczeństwa ruchu drogowego i warunków ich umieszczania na drogach. Dz. U. Nr 220/2003

[12] Sęk Ł. Polityka parkingowa w Polsce na przykładzie Warszawy i Wrocławia w świetle doświadczeń europejskich. Przegląd Komunikacyjny, nr 4-5-6/2010, str. 55 - 58

[13] Szarata A. Analiza wielkości parkingu Park and Ride zlokalizowanych w obszarach metropolitarnych. Budownictwo i Architektura, nr 13/2014, str. 267 - 274

[14] Vyhláška ze dne 12. srpna 2010, kterou se mění vyhláška č. 30/2001 Sb., kterou se provádějí pravidla provozu na pozemních komunikacích a uprava a řízení provozu na pozemních komunikacích, ve znění pozdějších předpisů

[15] Weiss A., Habib K. N. Examination the difference between park and ride and kiss and ride station choices using a spatially weighted error correlation (SWEC) discrete choice model. Journal of Transport Geography no. 59 (2017), str. 111 - 119

[16] www.openstreetmap.org, 22.01.2019

[17] www.szczecin.wyborcza.pl/szczecin/51,34939,19642331.html?i=1, 21.01.2019

[18] www.warszawa.wyborcza.pl/warszawa/51,34862,20070532.html?i=3, 21.01.2019 